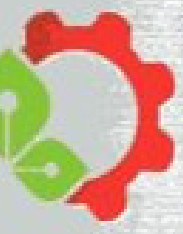

Kementerian Perindustrian REPUBLIK INDONESIA

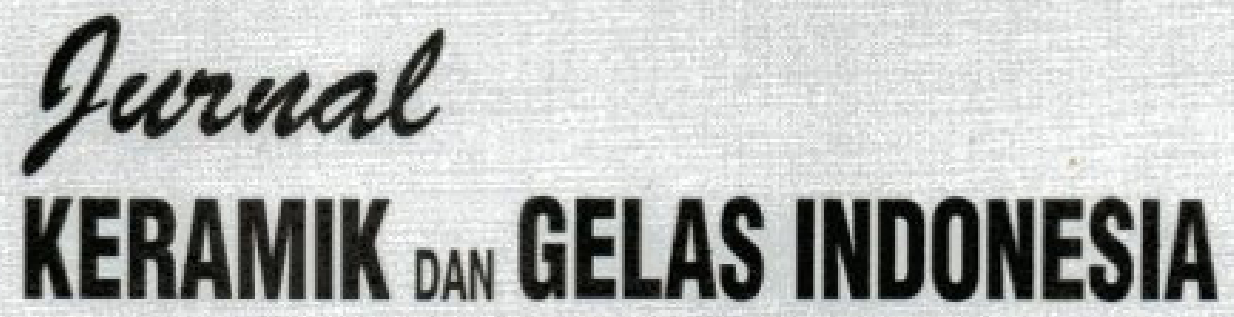

JOURNAL OF THE INDONESIAN CERAMICS AND GLASS

Vol. 25 No. 2. Desember 2016

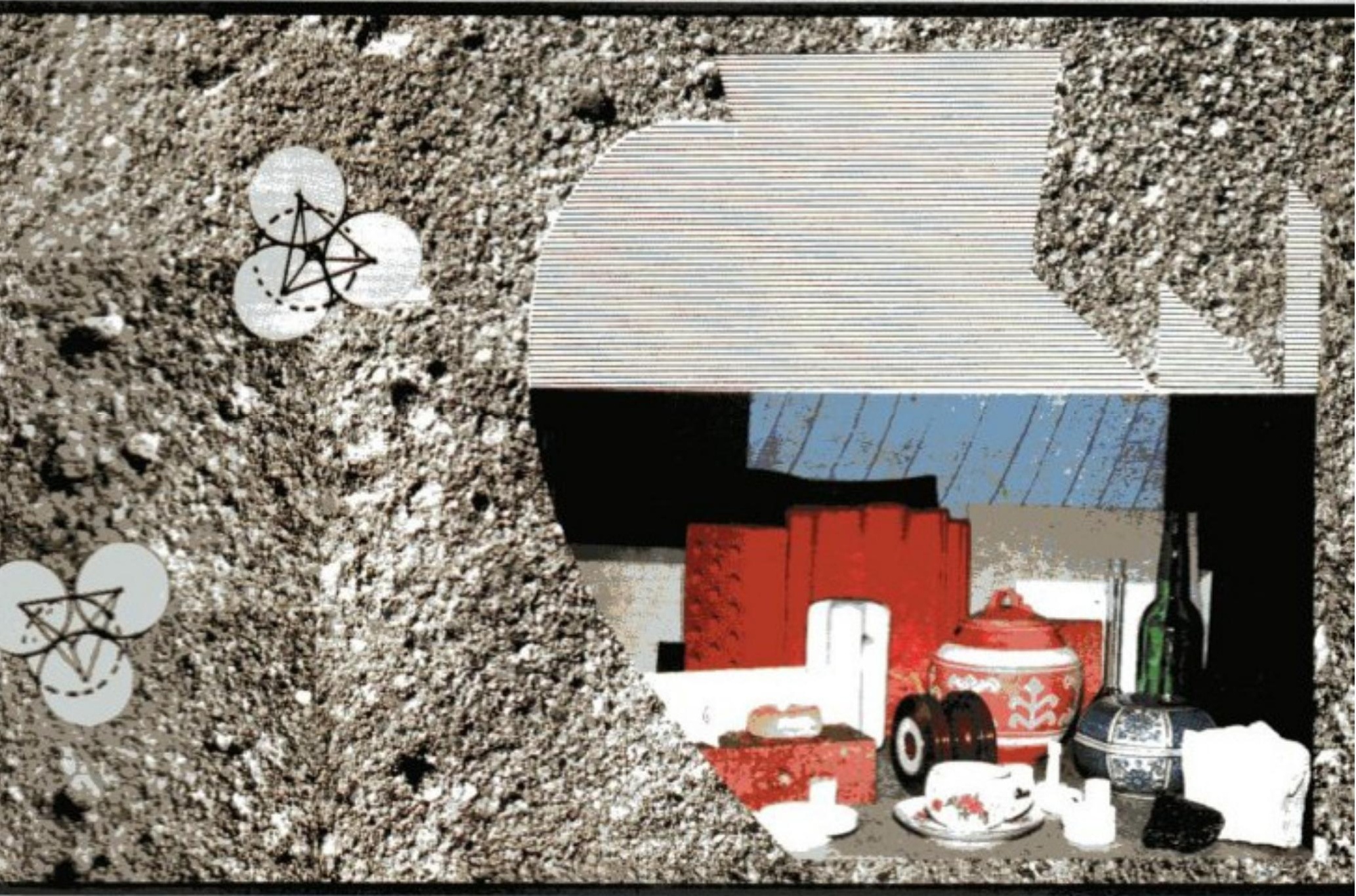

KEMENTERIAN PERINDUSTRIAN

BADAN PENELITIAN DAN PENGEMBANGAN INDUSTRI

BALAI BESAR KERAMIK

\begin{tabular}{|c|c|c|c|c|c|}
\hline JKGI & VOL. 25 & No.2 & Hal. 46-107 & $\begin{array}{c}\text { Bandung } \\
\text { Desember 2016 }\end{array}$ & $\begin{array}{c}\text { ISSN } \\
0854-5405\end{array}$ \\
\hline
\end{tabular}




\section{qurual \\ KERAMII ou GELAS INDONESIA \\ JOURNAL OF THE INDONESLAN CERAMICS AND GLASS}

\section{Vol. 25 No. 2. Desember 2016}

Jurnal Keramik dan Gelas Indonesia adalah majalah ilmiah yang diterbitkan dua kali dalam setahun untuk menyebarluaskan hasil-hasil penelitian dan pengembangan serta ulasan ilmiah tentang keramik dan gelas kepada lembaga penelitian dan pengembangan, ilmuwan dan peminat lainnya. Tulisan dalam Jumal

Keramik dan Gelas Indonesia dapat dikutip dengan menyebutkan sumbernya.

Penanggung Jawab

Kepala Balai Besar Keramik

Ir. Supomo, M.Sc.

Ketua Penyunting Merangkap Anggota

Ir. Hernawan, MT (Keramik Maju \& Gelas)

Penyunting Ahli

Dra. Sri Cicih Kurniasih, M.Si (Keramik Elektronik \& Nano Material)

Ir. Subari (Keramik Konvensional dan Pengetahuan Bahan)

Drs. Suhanda (Keramik Maju \& llmu Bahan)

\section{Mitra Bestari}

DR.Ir. Aristianto MMB, MSCE (Keramik Elektronik \& Keramik Struktural)

Dra, Naniek Sulistarihani, MS (Keramik Elektronik \& Keramik Struknra!)

Dr. Diana Rakhmawaty E, M.Si (Kimia Anorganik)

Prof. Dr. Ir. Tarzan Sembiring (Keramik Maju)

Drs. Fanani Hamzah, MS (Keramik Maju \& Gelas)

Sekretariat \& Redaksi Pelaksana

Dr. Handoko Setyo Kuncoro, ST, MT, M.Eng, PhD.

Nurhidayati, S.Si, MT.

Alamat Penyunting dan Tata Usaha

Balai Besar Keramik

Jl. Akhmad Yani No. 392 Bandung 40272

Telp: (022) 7206221,7207115, 7206296

Fax: (022) 7205322

e-mail:jkgi.bbk@gmail.com 


\section{qurnal \\ KERAMIK DAN GELAS INDONESIA}

JOURNAL OF THE INDONESIAN CERAMICS AND GLASS

Vol. 25 No. 2. Desember 2016

DAFTAR ISI

Halaman

1. Sintesis dan Karakterisasi Bone Ash Sintetik dari Bahan Alam

Characterization of Synthetic Bone Ash from Natural Sources

Kristanto Wahyudi, Frank Edwin dan Naili Sofyaningsih

$46-58$

2. Modifikasi Filter Keramik dengan Y-Alumina sebagai Adsorben Logam Berat

Modified Ceramic Filter with Y-Alumina Addition as Heavy Metals Adsorben

Eneng Maryani, Suhanda, Naili Sofyaningsih dan Ayu Ratnaningsih

3. Kajian Perkembangan Penelitian Glasir untuk Industri Keramik Selama 25 Tahun Terakhir

A Riview on The Glaze Researches Development Over The Last 25 Years in Center for Ceramics

Handoko Setyo Kuncoro, Herlina Damayanti dan Naili Sofyaningsih

$68-78$

4. Zirkonia untuk Aplikasi Material Restorasi Gigi

Zirconia as a Material for Dental Restorative Applications

LiaAsri, Rifki Septawendar dan Bambang Sunendar

$79 \cdot 88$

5. Sintesis dan Karakterisasi $\gamma$-Alumina Nanopartikel dari Garam Nitrat dengan Variasi Penambahan Polietilen Glikol (PEG)

Synthesis and Caharcaterization of Nanoparticle $\gamma$-alumina from Nitarte Salt with Variation of Polyethylen Glycol (PED)

Addition.

Raisa Khairani, Heri Setiawan dan Bambang Sunendar

$89-95$

6. Sintesis dan Karakterisasi Lempeung Terinterkalasi dengan Menggunakan Cetyl Pridinium hloride

Synthesis and Characterization of Clay Intercalation Using Cetyl Pridinium Chloride

Hernawan dan Nurhidayati 


\section{KATA PENGANTAR}

Jurnal Keramik dan Gelas Indonesia Vol. 25 No.2 Desember 2016 ini menyajikan 6 (enam) makalah yang ditulis oleh Peneliti Balai Besar Keramik dan instansi litbang lainnya. Makalah-makalah tersebut membahas sintesis dan karakterisasi bone ash sintetik dari bahan alam, modifikasi filter keramik dengan -alumina sebagai adsorben logam berat, kajian perkembangan penelitian glasir untuk industri keramik selama 25 tahun terakhir, bahan zirkonia untuk aplikasi material restorasi gigi, sintesis nanopartikelalumina dari garam nitrat dengan variasi penambahan polietilen glikol (PEG), dan sintesis lempung terinterkalasi dengan menggunakan cetyl pyridinium chloride.

Pada makalah pertama bahan baku alam yang digunakan untuk pembuatan bone ash sintetik diambil dari kapur Padalarang dan Cirebon dengan bahan pembentuk larutan asam fosfat teknis. Hasil karakterisasi XRD untuk pH 8-11 pada suhu kalsinasi $800^{\circ} \mathrm{C}$ menunjukkan hasil struktur kristal yang identik dengan tulang asli yang dibakar pada suhu $950^{\circ} \mathrm{C}$, yaitu kristal hidroksiapatit (HA). Sedangkan hasil FTIR menunjukan gugus yang dominan dari ikatan fosfat $\left(\mathrm{PO}_{4}{ }^{3}\right)$ pada bilangan gelombang $417 \mathrm{~cm}^{-1}$ dan $1084 \mathrm{~cm}$ dengan sebagian fraksi kecil gugus karbonat $\left(\mathrm{CO}_{3}{ }^{2}\right)$, gugus hidroksil $(\mathrm{OH})$, berturut-turut pada bilangan gelombang $1447 \mathrm{~cm}^{-1}$ dan $3417 \mathrm{~cm}^{-1}$.

Pada makalah kedua dipaparkan guna meningkatkan daya adsorpsi filter keramik terhadap logam berat maka dilakukan modifikasi filter dengan mengisi 80 gram adsorben -alumina ke dalamnya. Filter keramik yang dimodifikasi telah berhasil mengadsorpsi logam berat $(\mathrm{Pb}, \mathrm{Ar}$, dan $\mathrm{Cd})$ terutama $\mathrm{Pb}$ sehingga diperoleh kadar $\mathrm{Pb}$ sampai batas kuantifikasi alat pengukuran.

Pada makalah ketiga hasil-hasil penelitian glasir khususnya di Balai Besar Keramik akan dikaji dalam kaitannya dengan permasalahan di industri keramik di Indonesia. Hasil perhitungan dengan metode statistik ANOVA memberikan nilai $p$-value dibawah 0,05 dan perhitungan nilai $F 4,75$ (diatas kriteria $F 2,87$ ) yang menunjukkan bahwa penelitian-penelitian glasir selama ini memiliki hubungan yang signifikan dengan permasalahan di industri (IKM) keramik Indonesia.

Pada makalah keempat diulas mengenai perkembangan zirkonia sebagai material restorasi gigi, mulai dari struktur zirkonia, sifat mekanik, degradasi, aplikasi, sampai dengan studi in vivo dan in vitro. Selain itu juga dibahas mengenai prospek dan fokus penelitian zirkonia ke depan sebagai material restorasi gigi.

Pada makalah kelima ditunjukkan bahwa material gamma alumina $\left(-\mathrm{Al}_{2} \mathrm{O}_{3}\right)$ telah berhasil disintesis dengan prekursor aluminum nitrat $\left(\mathrm{Al}\left(\mathrm{NO}_{3}\right)_{3} \cdot 9 \mathrm{H}_{2} \mathrm{O}\right)$ pada variasi penambahan surfaktan polietilen glikol (PEG) 6000 (PEG/Al 0.133) sebagai dispersan dan pengarah struktur satu dimensi (template). Hasil analisis XRD dan SEM menunjukkan jenis fasa mineral gamma alumina (-Al2O3) dengan sebagian besar partikel $-\mathrm{Al}_{2} \mathrm{O}_{3}+\mathrm{PEG}$ memiliki morfologi berbentuk bulat dan sebagian lagi cenderung berbentuk batang dengan ukuran panjang sekitar $(40-70) \mathrm{nm}$ dan diameter $(10-20) \mathrm{nm}$. 
Pada makalah keenam ditunjukkan bahwa lebar jarak basal (antar lapis) dari montmorillonite dipengaruhi berat Cetylpyridinium chloride (CPC) ditambahkan terhadap berat $\mathrm{Na-Monmorilonit.} \mathrm{Indikasi} \mathrm{adanya} \mathrm{pelebaran} \mathrm{ditunjukkan} \mathrm{oleh} \mathrm{perubahan} \mathrm{posisi,}$ bentuk, dan intensitas hasil refleksi basal $\left(\mathrm{d}_{001}\right)$ pada difraktogram setelah dilakukannya proses interkalasi.

Hasil penelitian dan kajian di atas diharapkan dapat menyumbangkan kemajuan teknologi keramik di Indonesia, sehingga tidak tertinggal dengan kemajuan teknologi keramikglobal.

Redaksi selalu mengharapkan kritik dan saran dari para pembaca.

Redaksi 


\title{
KAJIAN PERKEMBANGAN PENELITIAN GLASIR UNTUK INDUSTRI KERAMIK SELAMA 25 TAHUN TERAKHIR
}

\author{
A Review on The Glaze Researches Development \\ Over The Last 25 Years in Center for Ceramics
}

Handoko Setyo Kuncoro, Herlina Damayanti dan Naili Sofiyaningsih

Balai Besar Keramik, Jl. Jendral Ahmad Yani 392 Bandung 40272 Tlp: (022) 7206221 e-mail: keramik@bbk.go.id

Naskah diterima : 10 Oktober 2016, Rev I : 20 Oktober 2016, Rev II : 07 Nopember 2016, Diterima : 21 Nopember 2016

ABSTRAK

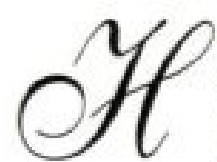

asil-hasil penelitian glasir Balai Besar Keramik akan dikaji dalam kaitannya dengan permasalahan di industri keramik di Indonesia. Kajian ini bertujuan mengevaluasi perkembangan penelitian glasir di Balai Besar Keramik (BBK) dalam keterkaitannya dengan topik yang diangkat dan permasalahan di industri keramik Indonesia. Perkembangan penelitian akan dikaji dalam rentang waktu 5 tahunan sesuai topiknya. Isu-isu industri juga diklasifikasikan kedalam 5 topik isu, yakni: bahan baku, teknologi proses, mutu produk, inovasi produk, dan lingkungan. Sampel data diambil dari penelitian-penelitian glasir mulai tahun 1992 hingga 2016 berdasarkan KTI Nasional dalam majalah JKGI dan ITKG. Sedangkan informasi tingkat permasalahan industri keramik didekati dari jajak pendapat 20 asesor industri keramik. Metode penelitian yang digunakan adalah metode statistik deskriptif dan inferensial ANOVA dengan tingkat kepercayaan 95\%. Hasil perhitungan ANOVA memberikan nilai $p$-value dibawah 0,05 dan perhitungan nilai $F 4,75$ (diatas kriteria $F 2,87$ ) yang menunjukkan bahwa penelitian-penelitian glasir selama ini memiliki hubungan yang signifikan dengan permasalahan di industri keramik Indonesia. Walaupun demikian, dalam kaitannya dengan industri keramik yang lebih besar, beberapa hal perlu ditingkatkan dalam penelitian bahan baku dan teknologi proses yang juga dibahas dalam kajian ini.

Kata Kunci: Penelitian glasir, masalah industri keramik, survei industri, statistik deskriptif, ANOVA, IKM. associated with industry issues were examined. This study purposed to evaluated glaze researches development in BBK relation to the observed topics and some issues at ceramic industry. Development of researches will be studied based of topic per 5 years. Industry issues also divided to 5 topics, namely: raw material, process technology, product quality, 
product innovation, and environment. Samples were taken from glaze researches at 1992 to 2016 in JKGI and ITKG magazines. While the information of issues level be approximated by polling opinion from 20 senior industrial assesors in ceramic industry. The used methods were a descriptive statistical method and inferential (ANOVA) with a $95 \%$ confidence level. The result of the ANOVA calculation gives $p$-value below 0.05 and $F$-value 4,75 (above $F$ 2,87 criteria), that indicated the observed research topics had significant relationship with ceramic industrial issues. However, for future studies, we have to improved the glaze researches especially the raw material and process technology topics for largerindustries.

Keywords: Glaze researches, ceramic industry issues, industrial survey, descriptive statistics, ANOVA, SMEs.

\section{PENDAHULUAN}

Glasir dapat di definisikan sebagai kombinasi bahan keramik yang didisain untuk lebur dan melekat sebagai pelapis gelasi (mirip kaca) pada bodi keramik yang dibakar.[1] Walaupun menurut sejarah pembuatan glasir pertama dilakukan 10,000 tahun yang lalu di Mesir, namun hal tersebut belum bisa dikatakan sebagai awal penelitian glasir karena pembuatannya ditemukan secara tidak sengaja (bukan melewati tahapan metode ilmiah).[1] Penelitian informal atau percobaan eksperimental tidak tertulis tentang glasir sebenarnya sudah banyak dilakukan dengan bukti-bukti perbaikan produk glasir hingga saat ini, namun hasil demikian kemungkinannya kecil untuk dikaji secara ilmiah karena tidak lengkapnya data yang menunjang untuk dikaji/diteliti. Dengan alasan tersebut kajian ini difokuskan pada hasil-hasil penelitian sebelumnya yang telah dipublikasikan terutama pada JKGI (Jurnal Keramik dan Gelas Indonesia) dan majalah ITKG (Informasi Teknologi Keramik dan Gelas) yang diterbitkan Balai Besar Keramik sebagai Instansi pemerintah yang memiliki TUPOKSI (Tugas Pokok dan Fungsi) khusus melaksanakan penelitian dan pengembangan produk industri keramik di Indonesia.

Bahan glasir rmenempati peringkat lebih tinggi dalam penelitian keramik dibanding penelitian untuk bodi keramik di industri besar. Teknologi glasir hampir dipakai dalam semua komoditas keramik seperti: ubin lantai dan dinding, saniter, table ware, keramik hias, dll. Hingga saat sudah dipublikasikan laporan penelitian glasir dalam bentuk sekitar 30 lebih karya tulis ilmiah [2-32] atau KTI yang diterbitkan majalah ilmiah. Hasil-hasil penelitian glasir dari tahun 1992 tersebut perlu untuk dievaluasi guna memberikan gambaran tingkat kematangan penelitian glasir di industri untuk kurun waktu 25 tahun terakhir. Hal ini juga akan memberikan 
gambaran peluang riset-riset glasir dimasa yang akan datang dan kesiapterapannya di industri keramik. Sayangnya hingga sekarang evaluasi penelitian atau kajian dalam bidang glasir yang diterbitkan dalam jurnal ilmiah termasuk langka dan jarang.

Ada dua pertanyaan penting yang selalu menjadi sorotan pada permasalahan perkembangan riset glasir di Indonesia, yakni apakah penelitianpenelitian glasir hingga saat ini sudah memiliki arah/panduan yang jelas terhadap mile-stone teknologi glasir dan apakah tujuan-tujuan penelitian tersebut berhubungan dengan keterkaitannya pada dunia industri keramik belum dieveluasi secara menyeluruh. Untuk bisa merespon pertanyaan tersebut, hipotesis bahwa topik penelitian-penelitian glasir Indonesia (selama 25 tahun terakhir) berhubungan dengan permasalahan pada dunia industri keramik masih perlu dikaji dan diuji. Hal ini bisa menunjukkan apakah penelitianpenelitian sebelumnya telah memiliki roadmap yang jelas pada pemenuhan kebutuhan industri. Disamping itu beberapa studi banding juga diperlukan untuk melihat kematangan hasil-hasil penelitian glasir di Indonesia umumnya dan di lingkungan Kementerian Perindustrian khususnya.

Tujuan penelitian ini adalah untuk mengkaji kembali hasil-hasil penelitianpenelitian glasir selama 25 tahun terakhir melalui telaah kronologis penelitian dan evaluasi statistik baik menggunakan analisis deskriptif maupun inferensi ANOVA (analysis of variance). Sampel penelitian yang diambil dibatasi pada masa 25 tahun terakhir dari majalah ilmiah JKGI dan ITKG. Sedangkan ranah permasalahan di industri keramik dibatasi dari hasil survei jajak pendapat beberapa asesor industri keramik yang sudah berpengalaman lebih dari 5 tahun.

\section{METODE PENELITIAN}

Beberapa point yang ingin dikaji dalam penelitian ini adalah perkembangan penelitian glasir beserta mile-stone-nya, program-program penelitiannya, hubungannya dengan permasalahan industri, dan peluang-peluang penelitian glasir untuk industri keramik.

\section{Kronologi Penelitian}

Perkembangan penelitian-penelitian glasir didekati dengan mengamati secara kronologis hasil-hasil dan topik-topik penelitian dalam periode waktu tertentu (lima tahunan). Observasi dilakukan untuk lima topik penelitian, yakni bahan baku, teknologi proses, mutu produk, inovasi produk dan lingkungan. Karya tulis ilmiah mulai tahun 1992 hingga sekarang diklasifikasikan menurut periode waktunya dalam 5 kelompok yakni: periode 19921996, periode 1997-2001, periode 20022006, periode 2007-2011 dan periode 2012-2016.

\section{Statistik Deskriptif}

Untuk mengetahui apakah ada program-program penelitian dalam penelitian glasir perlu dilakukan pendekatan statistik deskriptif yang meninjau jumlah penelitian per periode waktu. Kecenderungan jumlah penelitian bisa diperoleh dari metode regresi linier, dimana slope positif menunjukkan kenaikan sebaliknya slope negatif menunjukkan penurunan frekuensi 
penelitian. Program regresi ini telah tersedia di perangkat lunak Excel. Untuk lebih rincinya juga perlu diamati perubahan jumlah penelitian-penelitian glasir per topik masalah.

\section{Analysis of Variance (ANOVA)}

Faktor-faktor dalam ANOVA ditetapkan sebagai topik-topik masalah atau riset di industri keramik yang meliputi 5 topik sebelumnya. Karena hanya dicari hubungan topik penelitian dan prioritas/rangking permasalahan di industri, maka hanya akan dipakai metode ANOVA satu arah saja. Nilai permasalahan (Y) di industri keramik dalam kajian ini didekati dengan memperhatikan hasil perhitungan kuesioner 20 asesor industri keramik (bobot asesor) dan bobot dari sisi peneliti mengenai permasalahan industri keramik (bobot peneliti). Atau dapat diformulasikan secara sederhana:

$$
Y_{t q}=\text { frek } \times b_{\text {mesear }} \times b_{\text {pencin }}
$$

dimana indeks $t$ (topik) dan $p$ (periode) mewakili matrik 2 dimensi $(k \times l)$.

Sedangkan perhitungan ANOVA dan teori terkait mengikuti perhitungan standar statistik untuk ANOVA satu arah [33] dengan mengambil tingkat kepercayaan 95\%. Parameter ANOVA (yang umum digunakan dalam penelitian) meliputi:

SS (sum of squares)

$$
\overline{\bar{y}}=\frac{1}{n} \sum_{i=1}^{k} \sum_{j=1}^{n_{S}} y_{i j}
$$

between group

$$
\boldsymbol{S S R}=n_{\mathrm{S}} \sum_{i=1}^{k}\left(\overline{\mathrm{y}}_{\mathrm{i}}-\overline{\bar{y}}\right)^{2}
$$

within group

$$
\boldsymbol{S S E}=\sum_{\mathrm{i}=1}^{\mathrm{k}} \sum_{\mathrm{j}=1}^{n_{S}}\left(\mathrm{y}_{\mathrm{ij}}-\overline{\mathrm{y}}_{\mathrm{i}}\right)^{2}
$$

MS (mean of squares)

$$
\begin{gathered}
M S R=S S R / d f_{R} \\
M S E=S S E / d f_{E}
\end{gathered}
$$

dimana $d f$ merupakan derajat kebebasan. Harga F (F ratio)

$$
\boldsymbol{F}=M S R / M S E
$$

Jika $F$ hitung ini lebih besar dari $F$ kriteria maka ada hubungan signifikan antara topik yang diambil (faktor) dengan permasalahan industri keramik yang ada. Dalam kajian ini perhitungan ANOVA menggunakan program Excel dari Microsoft Office.

\section{Peluang Penelitian di Industri Keramik}

Peluang-peluang penelitian glasir akan diambil dari tiga prioritas topik utama berdasarkan permasalahan di industri. Hal tersebut sangat bergantung kepada hasil analisis dan pembahasan selanjutnya. Peluang ini juga diambil dari literatur glasir [1] mengacu pada kekurangankekurangan (kesulitan diterapkan pada industri besar) yang ada pada penelitianpenelitian sebelumnya. Nilai-nilai variabel dan optimasi untuk menghasilkan sesuatu yang diharapkan di industri keramik juga diperhatikan. Tidak menutup kemungkinan juga akan dibahas pengendalian proses di industri menyangkut beberapa mutu produk industri. Hal ini dikaji tidak lain hanya untuk memberikan potensi-potensi riset glasir supaya lebih dekat dengan aplikasinya di industri khususnya industri keramik. 


\section{HASIL DAN PEMBAHASAN}

Hasil-hasil kajian akan disajikan dalam empat bahasan utama yakni: kronologi penelitian, statistik deskriptif penelitian, keterkaitan penelitian dengan industri, dan peluang-peluang penelitian glasir.

\section{Bahasan Kronologi Penelitian Glasir}

Bahasan ini membagi periode penelitian glasir menjadi 5 periode sehingga masing-masing periode penelitian berdurasi 5 tahunan.

\section{Periode 1992-1996}

Pada periode ini sebagian penelitian mengarah pada perbaikan teknologi glasir dan beberapa diantaranya berfokus pada lingkungan (kesehatan).[2-9] Perbaikan teknologi ini meliputi pengembangan bahan baku glasir dan penelitianpenelitian tentang proses pembakaran beserta efeknya pada cacat glasir (seperti retak glasir). Sedangkan penelitian yang berorientasi pada lingkungan terkait dengan penggunaan frit timbal, glasir oksida lithium dan pengolahan limbah B3 dari lumpur elektroplating untuk bahan pewarna glasir. Adapun pengembangan bahan baku yang dihasilkan pada masa ini meliputi pembuatan glasir warna mat (kusam) dan pink (merah muda) serta penurunan kelas (down-grade) dari daur ulang limbah glasir ubin untuk bahan baku glasir gerabah.

\section{Periode 1997-2001}

Pada masa lima tahun kedua penelitian glasir [10-14] tidak hanya berfokus kepada pengembangan teknologi saja akan tetapi sudah dicoba mendekati kebutuhan di industri (kecil) khususnya pada pengembangan produk dan mutu glasir. Walaupun penelitian terkait kesehatan lingkungan nampak tidak dilakukan namun penelitian-penelitian lain tentang bahan baku dan proses glasir tetap dikembangkan. Untuk bahan baku telah berhasil dibuat glasir dengan warna turquiose blue (biru turki). Sedangkan untuk perbaikan proses, telah berhasil dilakukan penyederhanaan proses pembakaran dengan metoda single firing menggunakan oksida seng dan water glass. Penelitian lain tentang glasir lithium juga telah berhasil menurunkan suhu bakar proses dengan penambahan oksida boron. Pengembangan produk industri dimasa ini adalah penelitian penggunaan colemite untuk glasir bagi alat pemandu benang. Beberapa penyebab cacat glasir di industri beserta penanggulangannya juga diteliti untuk perbaikan mutu glasir.

\section{Periode 2002-2006}

Dalam periode ini topik-topik penelitian glasir mulai beragam.[15-23] Penelitian glasir yang berorientasi lingkungan kembali digiatkan dan beberapa kaji ulang pemanfaatan glasir bagi industri kecil juga dilakukan utamanya untuk produk keramik lokal. Penelitian tentang bahan baku (pewarna) glasir juga tetap dilakukan untuk mengembangkan bahan pewarna violet dari oksida kobalt (15\%) dengan variasi penelitian berupa rasio alumina:silika dalam julat (range) $0,05-0,089$. Warna glasir lain yang dikembangkan adalah warna coklat (mat / semi-mat / transparan) oleh penambahan oksida besi $(12 \%)$ dalam sistem glasir lime-barium. Penelitian yang terkait mutu dalam masa ini juga dilanjutkan, 
khususnya pengaturan penambahan bahan zirkon silikat dan temperatur bakar untuk menstabilkan warna merah dan hijau orange gelap. Sedangkan riset pengembangan produk baru difokuskan pada pembuatan produk glasir retak untuk keramik hias dengan mempertimbangkan muai panjang antara glasir dan bodi.

Periode 2007-2011

Hampir semua aspek atau arah penelitian dalam periode lima tahun ketiga diteruskan kembali untuk periode [24-30] penelitian glasir lima tahun keempat (2007-2011), kecuali penelitian yang berorientasi pada mutu nampak tidak dilanjutkan. Penelitian kajian masa ini sudah lebih spesifik dibanding sebelumnya, seperti penerapan glasir zirkon untuk gerabah merah bagi industri kecil. Pengembangan bahan baku juga lebih kreatif misalnya penggunaan $\mathrm{ZrSiO}_{4}$ untuk pembuatan glasir opaq serta riset penggunaan matrik alkali-alumina silikat dalam sistem glasir kristal $\left(\mathrm{ZnO}-\mathrm{SiO}_{2}\right)$. Pengembangan bahan ini juga diikuti dengan pengembangan produk seperti riset pembuatan glasir kristal willemite untuk keramik hias (dekoratif).

Sedangkan riset berorientasi kesehatan lingkungan diantaranya tentang pemanfaatan limbah porong sebagai bahan aditif glasir dan pemanfaatan serbuk silika dari limbah pengeboran gas.

\section{Periode 2012-2016}

Walaupun permasalahan glasir di industri masih banyak berpeluang diteliti, namun pada periode terakhir penelitian glasir [31-32] mulai menurun dan hanya terkait dengan proses dan pengembangan produk. Hal ini mengindikasikan roadmap dan program penelitian tentang glasir yang perlu diperbaiki. Untuk riset proses, telah dilakukan studi tentang kematangan glasir terhadap bodi keramik ditinjau dari sifat kimiawinya. Sedangkan untuk pengembangan produk telah berhasil dibuat produk glasir oribe (berwarna antara biru dan hijau) untuk keramik hias.

\section{Hasil Statistik Deskriptif Penelitian}

Berdasarkan bahasan kronologi penelitian glasir sebelumnya nampak secara garis besar topik penelitian bisa terbagi dalam 5 topik penelitian yakni: bahan baku, teknologi proses, mutu produk, inovasi produk dan lingkungan.

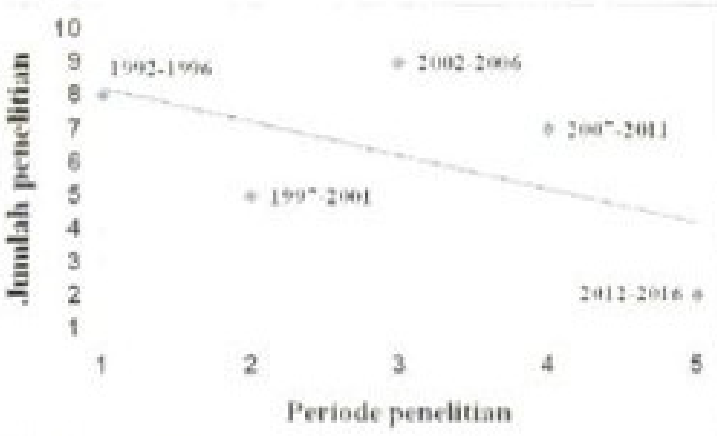

Gbr.1 Produktivitas penelitian glasir per periode

Untuk keseluruhan topik dari Gambar 1 nampak kecenderungan jumlah penelitian per periode (garis regresi linier) menurun dan turun drastik pada periode terakhir. Simpangan fluktuasi data yang begitu besar mengindikasikan belum terprogramnya arah penelitian-penelitian dalam 25 tahun terakhir.

Tabel 1. Jumlah penelitian sesuai topik

\begin{tabular}{c|ccccc} 
Periode & $\begin{array}{l}\text { Bahan } \\
\text { Baku }\end{array}$ & $\begin{array}{l}\text { Teknologi } \\
\text { Proses }\end{array}$ & $\begin{array}{c}\text { Mutu } \\
\text { Produk }\end{array}$ & $\begin{array}{c}\text { Inovasi } \\
\text { Produk }\end{array}$ & $\begin{array}{c}\text { Lingku- } \\
\text { ngan }\end{array}$ \\
\hline $\mathbf{1}$ & 2 & 1 & 3 & 0 & 2 \\
$\mathbf{2}$ & 1 & 2 & 1 & 1 & 0 \\
3 & 2 & 2 & 2 & 2 & 1 \\
$\mathbf{4}$ & 3 & 0 & 0 & 2 & 2 \\
5 & 0 & 0 & 1 & 1 & 0 \\
\hline Total & 8 & 5 & 7 & 6 & 5
\end{tabular}


Walaupun Tabel 1 diatas memberikan total penelitian yang hampir sama pada tiap topik penelitian yang dipilih, namun secara kronologis (dari periode ke periode berikutnya) tetap mengindikasikan jumlah penelitian per topik yang fluktuatif. Hal ini menunjukkan mile-stone penelitian per topik yang juga belum terprogram dengan baik.

Tabel. 2 Hasil survei pemeringkatan permasalahan industri keramik

\begin{tabular}{|c|c|c|c|c|c|c|}
\hline \multirow{2}{*}{ Kriteria Rangking } & \multicolumn{6}{|c|}{ Jumlah } \\
\cline { 2 - 7 } & 1 & 2 & 3 & 4 & 5 & Total \\
\hline Bahan Baku & 11 & 6 & 0 & 3 & 0 & 20 \\
\hline Proses & 3 & 2 & 10 & 3 & 2 & 20 \\
\hline Kualitas/Mutu & 5 & 7 & 4 & 3 & 1 & 20 \\
\hline Produk inovasi & 1 & 4 & 5 & 5 & 5 & 20 \\
\hline Lingkungan & 0 & 1 & 1 & 6 & 12 & 20 \\
\hline
\end{tabular}

Rangking 1:masalah bahan baku 2:masalah mutu 3 :masalah teknologi proses 4 :masalah inovasi produk 5 :masalah lingkungan

Dari hasil survei permasalahan industri dengan mengambil sampel 20 responden asesor industri keramik, urutan permasalahan industri keramik sesuai topiknya mulai dari masalah besar ke masalah yang lebih kecil adalah masalah bahan baku, mutu produk, teknologi proses, inovasi produk dan lingkungan. Meskipun hasil ini nampak tidak sesuai dengan urutan jumlah penelitian per topik dalam Tabel 1 namun hal tersebut belum menunjukkan hubungan antara kesesuaian topik penelitian dan permasalahan di industri, masih perlu dibuktikan/diuji dengan statistik inferensi ANOVA.

\section{Keterkaitan Penelitian dengan Industri}

Selain berbasis survei penilaian asesor, penilaian permasalahan industri juga mempertimbangkan bobot dari pihak peneliti.

Tabel 3. Tingkat permasalahan industri berdasarkan topiknya

\begin{tabular}{lccccc}
\hline Observasi & $\begin{array}{c}\text { Bahan } \\
\text { Baku }\end{array}$ & $\begin{array}{c}\text { Teknologi } \\
\text { Proses }\end{array}$ & $\begin{array}{c}\text { Mutu } \\
\text { Produk }\end{array}$ & $\begin{array}{c}\text { Inovasi } \\
\text { Produk }\end{array}$ & $\begin{array}{c}\text { Ungku- } \\
\text { ngan }\end{array}$ \\
\hline Periode 1 & 0.830 & 0.094 & 0.495 & 0.247 & 0.008 \\
Periode 2 & 0.500 & 0.427 & 0.124 & 0.126 & 0.000 \\
Periode 3 & 0.750 & 0.213 & 0.742 & 0.063 & 0.003 \\
Periode 4 & 1.250 & 0.000 & 0.000 & 0.126 & 0.010 \\
Periode 5 & 0.000 & 0.000 & 0.124 & 0.031 & 0.000
\end{tabular}

Hasilnya perhitungan tingkat permasalahan industri-keramik sesuai topiknya ditunjukkan dalam Tabel 1.

Uji statistik inferensi ANOVA satu arah mengambil tingkat kepercayaan 95\% yang berarti memberikan syarat signifikasi $5 \%$ atau 0,05 .

Tabel 4. Hasil perhitungan ANOVA

\begin{tabular}{lcccccc}
\hline Source of Voriation & SS & df & MS & $\boldsymbol{F}$ & P-value & $\boldsymbol{F}$ crit \\
\hline Between Groups & 1.318 & 4 & 0.329 & 4.747 & 0.007 & 2.866 \\
Within Groups & 1.398 & 20 & 0.069 & & & \\
& & & & & & \\
Total & 2.706 & 24 & & & & \\
\hline
\end{tabular}

Kolom SS merupakan hasil perhitungan jumlahan kuadrat (sum of squares) baik untuk antara grup maupun diantara grup. Kolom df merupakan derajat kebebasan (degree of freedom) dimana nilai antara grup adalah (5-1) sedangkan diantara grup 5(5-1). Rata-rata kuadrat MS (mean of squares) antara grup bernilai 0,329 sedangkan nilainya diantara grup adalah 0,069 . Sehingga harga $F$ menjadi $0,329 / 0,069$ atau 4,747 . Harga ini lebih besar dari $F$ kriteria 2,866 yang berarti topik-topik yang dipilih dalam penelitian berhubungan secara signifikan dengan permasalahan yang ada di industri 
khususnya di IKM. Nilai $p$-value $<0,05$ juga menguatkan hasil uji $F$-nya.

\section{Bahasan Peluang Penelitian Glasir di Industri(Besar)}

Tiga permasalahan industri keramik prioritas yang telah diidentifikasi adalah bahan baku, mutu produk, dan teknologi proses. Penelitian mutu produk di industri sangat erat kaitannya dengan cacat produk. Dalam hal teknologi glasir, cacat produk di industri keramik bisa berupa blistering (gelembung glasir), crazing (retak halus), crawling (bahan glasir masuk bodi), pinholing (lubang bintik-bintik), dunting (retak bodi), bloating (gelembung pada bodi), leaching (tidak tahan cuci/warna berubah), dan shivering (retak garis glasir). Sebab-sebab cacat bisa berasal dari kesalahan teknologi proses ataupun komposisi bahan. Karena itu penelitian dengan topik bahan baku dalam teknologi glasir juga memiliki peluang besar di industri keramik.

Tabel 5. Peluang penelitian di industri dengan topik teknologi proses.

\begin{tabular}{|c|c|c|}
\hline Topik Teknologi Proses & Variabel dan Optimasi & Resiko Cacat Glasir \\
\hline $\begin{array}{c}\text { Pembakaran pada temperatur } \\
\text { puncak }\end{array}$ & kecepatan bakar & Blistering \\
\hline $\begin{array}{l}\text { Pengaruh expansi termal bodi dan } \\
\text { glasir }\end{array}$ & komposisi bahan dan pembakaran & Crazing \\
\hline $\begin{array}{l}\text { Proses coating dan kebersihan } \\
\text { kerja }\end{array}$ & $\begin{array}{c}\text { ketebalan glasir dan kotoran yang } \\
\text { menempel }\end{array}$ & Crawling \\
\hline $\begin{array}{l}\text { Pengeringan sebelum glasir dan } \\
\text { penahanan suhu maksimum }\end{array}$ & $\begin{array}{c}\text { kadar air dan lama pembakaran } \\
\text { pada suhu puncak }\end{array}$ & Pinholing \\
\hline Proses pendinginan suhu tungku & perubahan suhu per menit & Dunting \\
\hline Pemanasan biskuit bodi & suhu pembakaran bodi & Bloating \\
\hline Penyesuaian formula glasir & $\begin{array}{c}\text { komposisi bahan berdasarkan leach } \\
\text { test dan ekspansi termal }\end{array}$ & Leaching, Shivering \\
\hline
\end{tabular}

Tabel 6. Peluang penelitian di industri dengan topik bahan baku.

\begin{tabular}{|c|c|c|}
\hline Topik Bahan Baku Glasir & Fungsi & $\begin{array}{l}\text { Isu pengendalian produk } \\
\text { di Industri }\end{array}$ \\
\hline Bahan penstabil (jenis clay) & $\begin{array}{l}\text { Untuk menahan melting dan } \\
\text { memadukan bodi }\end{array}$ & $\begin{array}{c}\text { Mengontrol kesesuaian } \\
\text { dengan bodi }\end{array}$ \\
\hline $\begin{array}{l}\text { Bahan flux (oksida lithium, } \\
\text { potasium, sodium) }\end{array}$ & Membantu melting glasir & $\begin{array}{c}\text { Mengontro/ kesesuaian } \\
\text { dengan bodi }\end{array}$ \\
\hline $\begin{array}{c}\text { Bahan frit (dari bahan flux dan } \\
\text { pembentuk gelas) }\end{array}$ & Mengurangi efek yang merugikan & $\begin{array}{l}\text { Mengontrol pinholing } \\
\text { dan sifat racun }\end{array}$ \\
\hline $\begin{array}{l}\text { Bahan pembentuk gelas (silika, } \\
\text { oksida boron) }\end{array}$ & $\begin{array}{l}\text { Memberikan matrik rangka bagi } \\
\text { glasir }\end{array}$ & Membuat efek glassy \\
\hline $\begin{array}{l}\text { Bahan opacifier (oksida timah, } \\
\text { titania, zirkonia) }\end{array}$ & $\begin{array}{c}\text { Membuat glasir tidak tembus } \\
\text { cahaya }\end{array}$ & $\begin{array}{c}\text { Membuat efek warna } \\
\text { opak }\end{array}$ \\
\hline $\begin{array}{l}\text { Bahan pewarna glasir (oksida } \\
\text { krom, kobalt, tembaga, besi) }\end{array}$ & Untuk memberi warna glasir & $\begin{array}{l}\text { Memberi efek tekstur } \\
\text { warna }\end{array}$ \\
\hline Stain & $\begin{array}{c}\text { Merupakan frit dari pewarna } \\
\text { glasir }\end{array}$ & $\begin{array}{l}\text { Pewarna lebih handal } \\
\text { dan aman }\end{array}$ \\
\hline Bahan aditif & $\begin{array}{c}\text { Sebagai bahan suspensi, } \\
\text { deflokulan, pengalir, anti susut }\end{array}$ & $\begin{array}{l}\text { Mengontrol proses } \\
\text { penglasiran }\end{array}$ \\
\hline
\end{tabular}


Tabel 5 dan Tabel 6 menunjukkan beberapa peluang penelitian glasir untuk memecahkan permasalahan industri keramik (industri besar) khususnya pada permasalahan penurunan mutu produk dan pengendalian proses produksi. Tabel 5 dilengkapi dengan variabel-variabel yang terkait untuk memudahkan optimasi penurunan cacat glasir melalui teknologi prosesnya di industri keramik. Tabel 6 juga dilengkapi dengan fungsi-fungsi bahan yang mempermudah penyelesaian isu-isu di industri keramik terkait dengan bahan bakunya.

\section{KESIMPULAN}

Berdasarkan kronologi penelitian, mile-stone penelitian-penelitian glasir dalam kurun waktu 25 tahun terakhir di BBK khususnya dan Indonesia umumnya perlu dibuatkan roadmap dan program yang lebih baik untuk penelitian glasir di masa mendatang.

- Hasil uji ANOVA untuk 31 sampel penelitian dan 20 data permasalahan industri dari survei asesor industri keramik mengindikasikan bahwa topik penelitian-penelitian glasir tersebut memiliki keterkaitan (hubungan yang signifikan) dengan permasalahanpermasalahan yang ada di industri keramik khususnya IKM.
Walaupun kecenderungan penelitian glasir semakin menurun jumlahnya, sebenarnya peluangpeluang penelitian glasir terkait masalah di industri besar masih terbuka khususnya untuk penelitian penurunan cacat produk dan pengendalian proses produksi.

\section{UCAPAN TERIMA KASIH}

Penulis memberikan apresiasi yang setinggi-tingginya kepada industri keramik Indonesia yang telah memberikan informasi dalam kajian ini. Tidak lupa kami ucapkan terima kasih yang sebesar-besarnya kepada para peneliti dan asesor industri yang memberikan hasil survei dalam kajian ini.

\section{DAFTAR PUSTAKA}

1. Bryan Taylor dan Kate Doody, "Ceramics Glaze", Thames \& Hudson, 2014

2. Suparta AR dan M Hombas,"Aspek Pemakaian Glasir Frit Timbal untuk Gerabah Hias", Informasi Teknologi Keramik dan Gelas 13 [53] (1992)

3. Soesilowati dan CK Dede, "Pemanfaatan Limbah Glasir Industri Ubin Keramik untuk Glasir Gerabah", Informasi Teknologi Keramik dan Gelas 13 [55] (1992)

4. Sunarto dan Hidayat Ade, "Penelitian Pewarna Zinc Alumina Chrom untuk Pembuatan Glasir Pink", Informasi 
Teknologi Keramik dan Gelas 14 [57] tahun (1993)

5. K Haryono dan Suparyo Yoyo, "Peningkatan Nilai Tambah Abu Kayu Karet untuk Pembuatan Glasir Kusam dan Mat", Informasi Teknologi Keramik dan Gelas 14 [57] (1993)

6. Djuhaningsih Djuju, "Pengaruh Kecepatan Pembakaran terhadap Angka Muai Panjang Glasir", Informasi Teknologi Keramik dan Gelas 14 [62-63](1994)

7. Hamzah Fanani, "Glasir Litium untuk Suhu Pembakaran dibawah 10000 C", Jurnal Keramik dan Gelas Indonesia 3 [1] (1994)

8. Sagala Meda, Soesilowati, dan Suhanda, "Pembuatan Glasir Berwarna dari Limbah Lumpur Elektropleting", Jurnal Keramik dan Gelas Indonesia 3 [2] (1994)

9. Supomo dan Sagala Meda, "Interaksi Lapisan Glasir dan Bodi Ubin Keramik Bakaran Cepat", Jurnal Keramik dan Gelas Indonesia 4 [2] (1995)

10. Suripto dan Fajar Agus, "Penambahan Water Glass dan Seng Oksida dalam Slip Glasir Timbal untuk Penerapan Metode Single Firing pada Pembakaran Genteng Berglasir di Industri Kecil", Jurnal Keramik dan Gelas Indonesia 6 [2] (1997)

11. Soesilowati, "Pemanfaatan Warna Glasir Turkey Biru (Turquiose Blue) untuk Keramik Seni", Informasi Teknologi Keramik dan Gelas 10 [38] (1998)

12. Enymia dan Nugroho Yanto, "Pengaruh Colemanit dalam Meningkatkan Mutu Glasir pada Alat
Pemandu Benang", Jurnal Keramik dan Gelas Indonesia 8 [1] dan [2] (1999)

13. Hamzah Fanani, "Pengaruh Penamabhan Oksida Boron terhadap Karakteristik Glasir Litium", Jurnal Keramik dan Gelas Indonesia 8 [1] dan [2] (1999)

14. Supomo, "Analisa Penyebab dan Cara Penanggulangan Cacat Glasir pada Produk Keramik Konvensional", Jurnal Keramik dan Gelas Indonesia 10 [2] (2001)

15. Soesilowati dan Suhanda, "Penambahan Oksida Kobalt dalam Modifikasi Glaisr Warna Violet dengan peningkatan Nilai Perbandingan Al2O3 dan SiO2", Jurnal Keramik dan Gelas Indonesia 12 [1] (2003)

16. Nuryanto, Wenas RIF, dan Soesilowati, "Pengembangan Warna Glasir dengan Penambahan Oksida pada Lime Barium Glaze", Jurnal Keramik dan Gelas Indonesia 12 [2] (2003)

17. Nugroho Yanto dan Wenas RIF, "Daur Ulang Glasir Limbah Industri Keramik", Informasi Teknologi Keramik dan Gelas 25 [1] (2004)

18. Suripto dan Kurniawan Dede Cahli, "Glasir Berpotensi meningkatkan Nilai Tambah Industri Kecil Keramik", Informasi Teknologi Keramik dan Gelas 25 [2] (2004)

19. Soesilowati, Rachman Cumilah, dan Angreini Diyan, "Pengaruh Penambahan Zirkon terhadap Warna Glasir Merah", Informasi Teknologi Keramik dan Gelas 26 [1] (2005) 
20. Soesilowati dan Suhanda, "Peran Fasa Gelas untuk Meredam Limba B3 (Logam Berat) dan Pemanfaatannya sebagai Glasir", Jurnal Keramik dan Gelas Indonesia 14 [2] (2005)

21. Suripto dan W Sri Hidayati, "Pengembangan Produk Keramik dan Glasir dengan Memanfaatkan Bahan Baku Lokal Desa Pulutan Propinsi Sulawesi Utara", Jurnal Keramik dan Gelas Indonesia 15 [1] (2006)

22. Suhanda dan Soesilowati, "Limbah Kertas sebagai Bahan Glasir Sistem $\mathrm{Na}_{2} \mathrm{O}-\mathrm{CaO}-\mathrm{B}_{2} \mathrm{O}_{3}-\mathrm{SiO}_{2}{ }^{\circ}$, Jurnal Keramik dan Gelas Indonesia 15 [1] (2006)

23. Soesilowati dan Djuhaningsih Djuju, "Pembuatan Glasir Retak (Crackle) untuk Keramik Hias/seni dengan Pengaturan Angka Muai Panjang", Jurnal Keramik dan Gelas Indonesia 15 [2] (2006)

24. Subari dan Djuhaningsih Djudju, Percobaan Pembuatan Glasir Frit dan Glasir Mentah untuk Konsumsi Industri Kecil keramik", Informasi Teknologi Keramik dan Gelas 28 [2] (2007)

25. Wenas RIF dan Subari, "Pemanfaatan Serbuk Silika Hasil Pengolahan Limbah Pengeboran gas Alam di Dieng sebagai Bahan Glasir Keramik", Jurnal Keramik dan Gelas Indonesia 16 [2] (2007)

26. Soesilowati dan W Sri Hidayati, "Aplikasi Glasir Zirkon pada Industri Gerabah Keramik", Informasi Teknologi Keramik dan Gelas 29 [2]
(2008)

27. Nugroho Yanto, "Glasir Kristal Willemite sebagai Dekoratif Keramik", Jurnal Keramik dan Gelas Indonesia 18 [2] (2009)

28. Soesilowati, Suhanda, dan Mulyana, "Pembentukan Glasir Kristal Sistem $\left(\mathrm{ZnO}-\mathrm{SiO}_{2}\right)$ dalam Matrik Alkali Alumino Silikat", Informasi Teknologi Keramik dan Gelas 31 [1] (2010)

29. Subari dan W Sri Hidayati, "Pemanfaatan Limbah Porong sebagai Bahan Aditif pada Pembuatan Glasir", Informasi Teknologi Keramik dan Gelas 31 [1] (2010)

30. Suparyo Yoyo dan Subari, "Pengaruh Penggunaan Silika dan Zirkon pada Komposisi Glasir Keramik Konvensional", Informasi Teknologi Keramik dan Gelas 31 [2] (2010)

31. Soesilowati, "Pemanfaatan Glasir Oribe untuk Keramik Hias dan Keramik Seni", Informasi Teknologi Keramik dan Gelas 33 [1] (2012).

32. Sofiyaningsih Naili dan Soesilowati, "Sifat Kimia Glasir terhadap Kematangan Bodi Keramik", Informasi Teknologi Keramik dan Gelas 36 [2] (2015).

33. Ranjit K Ray, "A Primer on The Taguchi Method", Society of Manufacturing Engineers, 2010. 